\title{
The use of the ph1b mutant to induce recombination between the chromosomes of wheat and barley
}

\author{
Maria-Dolores Rey, María C. Calderón and Pilar Prieto * \\ Plant Breeding Department, Institute for Sustainable Agriculture, Agencia Estatal Consejo Superior de Investigaciones \\ Científicas, Córdoba, Spain
}

\section{OPEN ACCESS}

Edited by:

Soren K. Rasmussen,

University of Copenhagen, Denmark

Reviewed by:

Sergio Lanteri,

University of Turin, Italy

Juan Manuel Vega,

Universidad Complutense de Madrid,

Spain

Tomás Naranjo,

Universidad Complutense de Madrid,

Spain

${ }^{*}$ Correspondence:

Pilar Prieto,

Plant Breeding Department, Institute for Sustainable Agriculture, Agencia

Estatal Consejo Superior de Investigaciones Científicas, Avenue

Menéndez Pidal s/n, Campus Alameda del Obispo, Apartado 4084, Córdoba 14080, Spain pilar.prieto@ias.csic.es

Specialty section:

This article was submitted to Crop Science and Horticulture, a section of the journal Frontiers in Plant Science

Received: 19 January 2015 Accepted: 01 March 2015

Published: 19 March 2015

Citation:

Rey M-D, Calderón MC and Prieto $P$ (2015) The use of the ph1b mutant to induce recombination between the chromosomes of wheat and barley.

Front. Plant Sci. 6:160. doi: 10.3389/fp/s.2015.00160
Intensive breeding has led to a narrowing in the genetic base of our major crops. In wheat, access to the extensive gene pool residing in its many and varied relatives (some cultivated, others wild) is hampered by the block on recombination imposed by the Ph1 (Pairing homoeologous 1) gene. Here, the ph1b mutant has been exploited to induced allosyndesis between wheat chromosomes and those of both Hordeum vulgare (cultivated barley) and $H$. chilense (a wild barley). A number of single chromosome Hordeum sp. substitution and addition lines in wheat were crossed and backcrossed to the ph1b mutant to produce plants in which pairing between the wheat and the non-wheat chromosomes was not suppressed by the presence of Ph1. Genomic in situ hybridization was applied to almost $500 \mathrm{BC}_{1} \mathrm{~F}_{2}$ progeny as a screen for allosyndetic recombinants. Chromosome rearrangements were detected affecting $H$. chilense chromosomes $4 \mathrm{H}^{\mathrm{ch}}, 5 \mathrm{H}^{\mathrm{ch}}, 6 \mathrm{H}^{\mathrm{ch}}$, and $7 \mathrm{H}^{\mathrm{ch}}$ and $\mathrm{H}$. vulgare chromosomes $4 \mathrm{H}^{\mathrm{v}}$, $6 \mathbf{H}^{\mathbf{v}}$, and $7 \mathbf{H}^{\mathrm{v}}$. Two of these were clearly the product of a recombination event involving chromosome $4 \mathbf{H}^{\text {ch }}$ and a wheat chromosome.

Keywords: Triticum, Hordeum substitution and addition lines, Ph1 locus, wheat breeding, recombination, meiosis

\section{Introduction}

Bread wheat (Triticum aestivum) is one of the most important food crops of the world, and continuous improvement in its productivity will be required to keep pace with global population growth. The genetic base of the species is rather narrow, as its speciation was very recent (Salamini et al., 2002; Riehl et al., 2013). However, a large number of sexually compatible species (some wild and some cultivated) are known, and these represent a much needed reservoir of potentially exploitable genetic variation.

The genome of an interspecific or (intergeneric) hybrid combines the haploid complements of each of its sexual parents. Even though their genomes are closely related to one another, in most cases, the chromosomes of wheat and those of its relatives fail to pair with one another and thus allosyndetic recombination is rare. The failure of homoeologs (chromosomes from related genomes but not completely homologous) to pair at meiosis is ensured by the wild type allele at the Ph1 locus (Riley and Chapman, 1958; Sears and Okamoto, 1958; Sears, 1976). This gene imposes diploid-like chromosome behavior during meiosis, even though the constituent sub-genomes of this hexaploid species are known to be very closely related to one another. Deletion of the $P h 1$ locus allows homoeologs to pair relatively freely with one another (Moore, 2014), a situation which 
TABLE 1 | Plants used for crosses made to engineer individuals carrying a Hordeum sp. chromosome in a ph1b mutant background.

\begin{tabular}{|c|c|c|c|c|c|c|}
\hline \multicolumn{4}{|c|}{ Initial parental lines } & \multicolumn{3}{|c|}{ Descendence } \\
\hline \multicolumn{3}{|c|}{ Wheat line (female), nomenclature and number of plants used } & \multirow{2}{*}{$\begin{array}{l}\text { CSph1ph1 } \\
\text { (male) }\end{array}$} & \multirow{2}{*}{$\begin{array}{l}\mathbf{F 1} \\
15\end{array}$} & \multirow{2}{*}{$\begin{array}{l}\text { BC1F1 } \\
17\end{array}$} & \multirow{2}{*}{$\begin{array}{l}\text { BC1F2 } \\
30\end{array}$} \\
\hline (4B) $4 \mathbf{H}^{\text {ch }}$ disomic substitution line & $\mathrm{CS}(4 \mathbf{B}) 4 \mathbf{H}^{\mathrm{ch}}$ & 5 & & & & \\
\hline (4D) $4 \mathbf{H}^{\text {ch }}$ disomic substitution line & $\mathrm{CS}(4 \mathbf{D}) 4 \mathbf{H}^{\mathrm{ch}}$ & 5 & 3 & 11 & 15 & 48 \\
\hline$(5 \mathbf{A}) 5 \mathbf{H}^{\text {ch }}$ disomic substitution line & $\mathrm{CS}(5 \mathbf{A}) 5 \mathbf{H}^{\mathrm{ch}}$ & 5 & 3 & 16 & 22 & 12 \\
\hline (5B) $5 \mathbf{H}^{\text {ch }}$ disomic substitution line & $\operatorname{CS}(5 \mathbf{B}) 5 \mathbf{H}^{\mathrm{ch}}$ & 5 & 3 & 15 & 48 & 30 \\
\hline (5D) $5 \mathbf{H}^{\text {ch }}$ disomic substitution line & $\mathrm{CS}(5 \mathbf{D}) 5 \mathbf{H}^{\mathrm{ch}}$ & 5 & 3 & 11 & 22 & 20 \\
\hline (7A) $7 \mathbf{H}^{\text {ch }}$ disomic substitution line & $\operatorname{CS}(7 \mathbf{A}) 7 \mathbf{H}^{\mathrm{ch}}$ & 5 & 3 & 21 & 47 & 77 \\
\hline (7B) $7 \mathbf{H}^{\text {ch }}$ disomic substitution line & $\operatorname{CS}(7 \mathbf{B}) 7 \mathbf{H}^{\mathrm{ch}}$ & 5 & 3 & 19 & 59 & 64 \\
\hline (7D) $7 \mathbf{H}^{\text {ch }}$ disomic substitution line & $\mathrm{CS}(7 \mathbf{D}) 7 \mathbf{H}^{\mathrm{ch}}$ & 5 & 3 & 19 & 36 & 40 \\
\hline $5 \mathbf{H}^{\text {ch }}$ disomic addition line & $5 \mathbf{H}^{\mathrm{ch}}$ addition & 5 & 3 & 5 & 27 & - \\
\hline $6 \mathbf{H}^{\text {ch }}$ disomic addition line & $6 \mathbf{H}^{\text {ch }}$ addition & 5 & 3 & 29 & 35 & 20 \\
\hline $7 \mathbf{H}^{\text {ch }}$ disomic addition line & $7 \mathbf{H}^{\text {ch }}$ addition & 5 & 3 & 16 & 21 & 25 \\
\hline Total of wheat- $H$. chilense plants & & 55 & 33 & 177 & 349 & 366 \\
\hline $2 \mathbf{H}^{\mathbf{v}}$ disomic addition line & $2 \mathbf{H}^{\mathbf{v}}$ addition & 5 & 3 & 11 & 20 & - \\
\hline $4 \mathbf{H}^{\mathbf{v}}$ disomic addition line & $4 \mathbf{H}^{\mathbf{v}}$ addition & 5 & 3 & 15 & 52 & 46 \\
\hline $6 \mathbf{H}^{\mathbf{v}}$ disomic addition line & $6 \mathbf{H}^{\mathbf{v}}$ addition & 5 & 3 & 23 & 33 & 23 \\
\hline $\mathbf{7} \mathbf{H}^{\mathbf{v}}$ disomic addition line & $7 \mathbf{H}^{\mathbf{v}}$ addition & 5 & 3 & 21 & 28 & 38 \\
\hline Total of wheat-H.vulgare plants & & 20 & 12 & 70 & 133 & 107 \\
\hline Total & & 75 & 45 & 218 & 482 & 473 \\
\hline
\end{tabular}

CS, wheat cv. Chinese Spring; $\boldsymbol{H}^{c h}, \boldsymbol{H}$. chilense; $\boldsymbol{H}^{v}, \boldsymbol{H}$. vulgare.

TABLE 2 | DNA-based markers used as genotypic assays for the presence of specific Hordeum sp. chromosomes.

\begin{tabular}{|c|c|c|c|}
\hline $\begin{array}{l}\text { Marker } \\
\text { name }\end{array}$ & Sequence of primers $\left(5^{‘} \rightarrow 3^{\prime}\right)$ & $\begin{array}{l}\text { Hordeum } \\
\text { chromo- } \\
\text { some }\end{array}$ & $\begin{array}{l}\text { Annealing } \\
\text { temperature } \\
\left({ }^{\circ} \mathrm{C}\right)\end{array}$ \\
\hline BAWU759-F & TCGACATCTCTCCCATITCCC & $2 \mathbf{H}-\mathrm{S}$ & 50 \\
\hline BAWU759-R & AACCAGATATGGATGCCAGG & $2 \mathbf{H}-\mathrm{S}$ & 50 \\
\hline HVCSG-F* & $\begin{array}{l}\text { CACTTGCCTACCTCGATA } \\
\text { TAGTITGC }\end{array}$ & $2 \mathbf{H}^{\mathbf{v}}-\mathrm{L}$ & 50 \\
\hline HVCSG-R* & $\begin{array}{l}\text { GTGGATTCCATGCATGCA } \\
\text { ATATGTGG }\end{array}$ & $2 \mathbf{H}^{\mathbf{v}}-\mathrm{L}$ & 50 \\
\hline BAWU303-F & AATGTGCCTCCACAGGGTAG & $4 \mathbf{H}-\mathrm{S}$ & 55 \\
\hline BAWU303-R & GATACTGAGTGGAAAGCGGC & $4 \mathbf{H}-\mathrm{S}$ & 55 \\
\hline BAWU808-F & TGCCCCCAAACTITATATGC & $4 \mathbf{H}-\mathrm{L}$ & 55 \\
\hline BAWU808-R & GAGGGTCTTCCTGTTGTGGA & $4 \mathbf{H}-\mathrm{L}$ & 55 \\
\hline BAWU131-F & GAACGCCAGCCAAATTGTAT & $5 \mathbf{H}-\mathrm{S}$ & 60 \\
\hline BAWU131-R & ACCATITGATCCTTCTGCG & $5 \mathbf{H}-\mathrm{S}$ & 60 \\
\hline BAWU782-F & CAACTTGGACAACACAACGC & $5 \mathbf{H}-\mathrm{L}$ & 60 \\
\hline BAWU782-R & CTTGTGCATGCGCAGAGTAT & $5 \mathbf{H}-\mathrm{L}$ & 60 \\
\hline BAWU94-F & TाTCAAGCAGAGCTGCAAAG & $6 \mathbf{H}-\mathrm{S}$ & 55 \\
\hline BAWU94-R & GCTTGCTGAGCGCTITCTAC & $6 \mathbf{H}-\mathrm{S}$ & 55 \\
\hline BAWU107-F & CGCCTATITCTGAGCTCCTG & $6 \mathbf{H}-\mathrm{L}$ & 55 \\
\hline BAWU107-R & CGAGTATGGGAGTGGCAGTT & $6 \mathbf{H}-\mathrm{L}$ & 55 \\
\hline BAWU763-F & AGAACCGAGATGAGGAATGTG & $7 \mathbf{H}-\mathrm{S}$ & 58 \\
\hline BAWU763-R & AGTCTCTTCGCGGAATCAAG & $7 \mathbf{H}-\mathrm{S}$ & 58 \\
\hline BAWU550-F & ATGCCACCATTTACAAAGCC & $7 \mathbf{H}-\mathrm{L}$ & 50 \\
\hline BAWU550-R & TICTGGGTCCTGATCCTTG & $7 \mathbf{H}-\mathrm{L}$ & 50 \\
\hline
\end{tabular}

F, Forward primer; $R$, reverse primer; $\boldsymbol{H}^{v}, \boldsymbol{H}$. vulgare; $\boldsymbol{H}, \boldsymbol{H}$. chilense and $\boldsymbol{H}$. vulgare. has been exploited for introgression purposes through the use of the ph1b mutant (Riley et al., 1968b; Sears, 1977, 1981, 1982; Khan, 1999; Lukaszewski, 2000; Qi et al., 2008; Liu et al., 2011; Zhao et al., 2013).

Hordeum chilense, a species which is readily crossable with wheat, is a diploid relative of cultivated barley. It has been identified as a potential donor to wheat for a number of traits of agronomic interest (Martín et al., 1998, 2000). The bread wheat $\times H$. chilense hybrid has been the source of a collection of single (Hordeum) chromosome addition lines and chromosome substitution lines in a bread wheat genetic background (Miller et al., 1982), and similar cytogenetic stocks have been developed involving the cultivated barley ( $H$. vulgare) chromosomes (Islam et al., 1978, 1981). The self-fertile amphidiploid Tritordeum represents the product of chromosome doubling of the hybrid T. turgidum $\times H$. chilense (Martín and Sanchez-Mongelaguna, 1982). The presence of Ph1 maintains the integrity of Hordeum sp. chromosome(s) in all of this germplasm, meaning that the introgression of favorable non-wheat genes is inevitably accompanied by the inheritance of a large number of unwanted ones. The experience with introgression into wheat from other related species suggests that this linkage drag can best be overcome by employing a phlb-based strategy. Here, we describe progress made with an introgression program using the ph1b mutant to induce chromosome pairing and recombination between the chromosomes of $H$. chilense or $H$. vulgare, and those of wheat. 

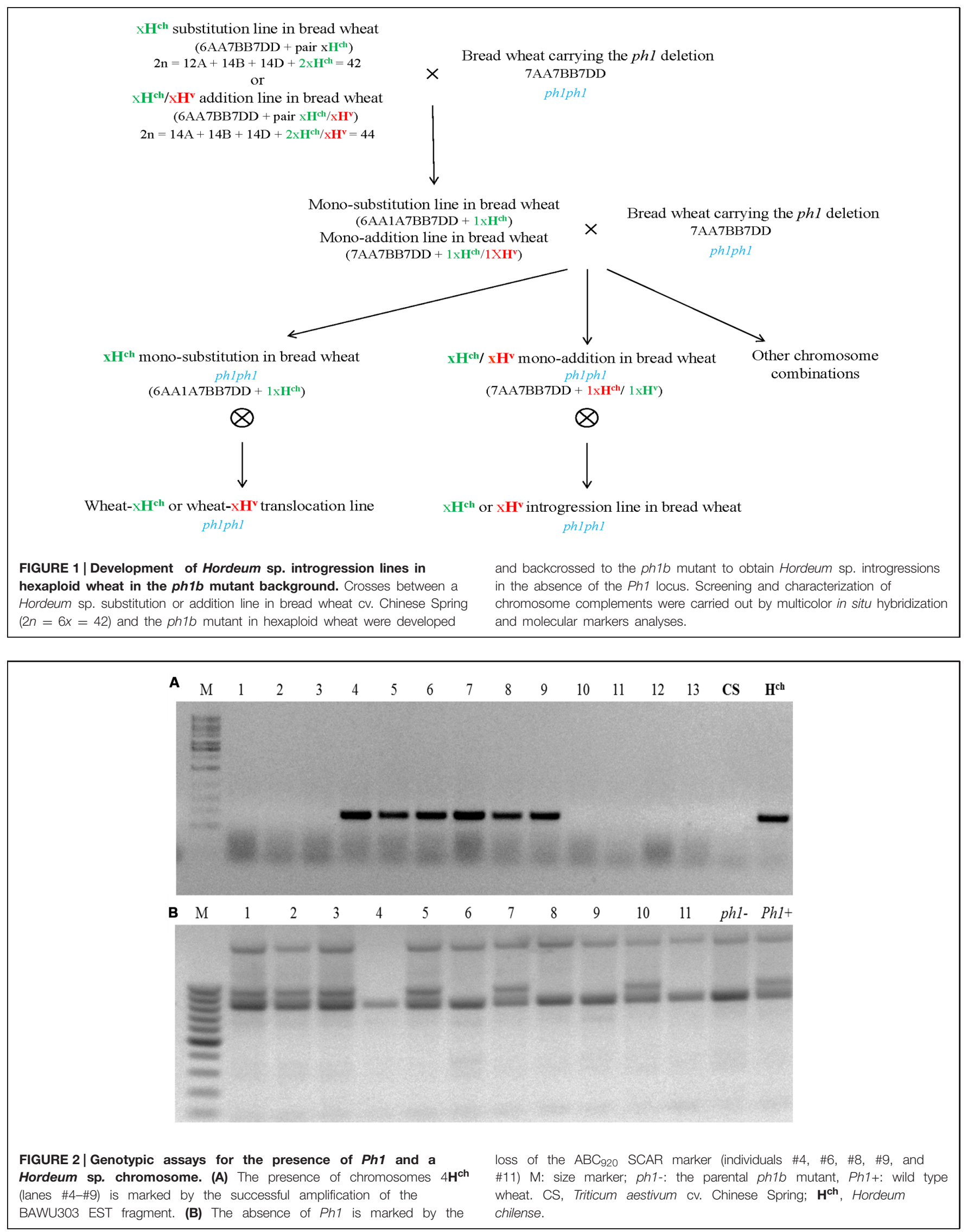
TABLE 3 | The frequency of allosyndesis involving a Hordeum and a wheat chromosome in either the presence (Ph1+) or absence (ph1-) of the Ph1 locus.

\begin{tabular}{|c|c|c|c|c|c|c|c|c|}
\hline $\begin{array}{l}\text { Wheat } \\
\text { line }\end{array}$ & $\begin{array}{l}\text { Hordeum sp. } \\
\text { introgressed }\end{array}$ & $\begin{array}{l}\text { No of plants } \\
\text { analyzed }\end{array}$ & $\begin{array}{l}\text { No of plants } \\
\text { showing } \\
\text { wheat-Hordeum } \\
\text { pairing }\end{array}$ & $\begin{array}{l}\text { Frequency of } \\
\text { wheat-Hordeum } \\
\text { pairing (\%) }\end{array}$ & $\begin{array}{l}\text { No of } \\
\text { PMCs } \\
\text { scored }\end{array}$ & $\begin{array}{l}\text { No of PMCs } \\
\text { scored showing } \\
\text { wheat-Hordeum } \\
\text { pairing }\end{array}$ & $\begin{array}{l}\text { Frequency of } \\
\text { wheat-Hordeum } \\
\text { pairing in PMCs } \\
(\%)\end{array}$ & $p$-value \\
\hline $\mathrm{Ph}^{+}$ & & 5 & 0 & 0.00 & 206 & 0 & 0.00 & $p=0.000^{* * *}$ \\
\hline \multirow[t]{3}{*}{ ph1- } & H. chilense & 42 & 19 & 45.23 & 2422 & 43 & 1.77 & \\
\hline & H. vulgare & 21 & 13 & 61.90 & 1352 & 25 & 1.84 & \\
\hline & Total & 63 & 32 & 53.56 & 3774 & 67 & 1.80 & \\
\hline
\end{tabular}
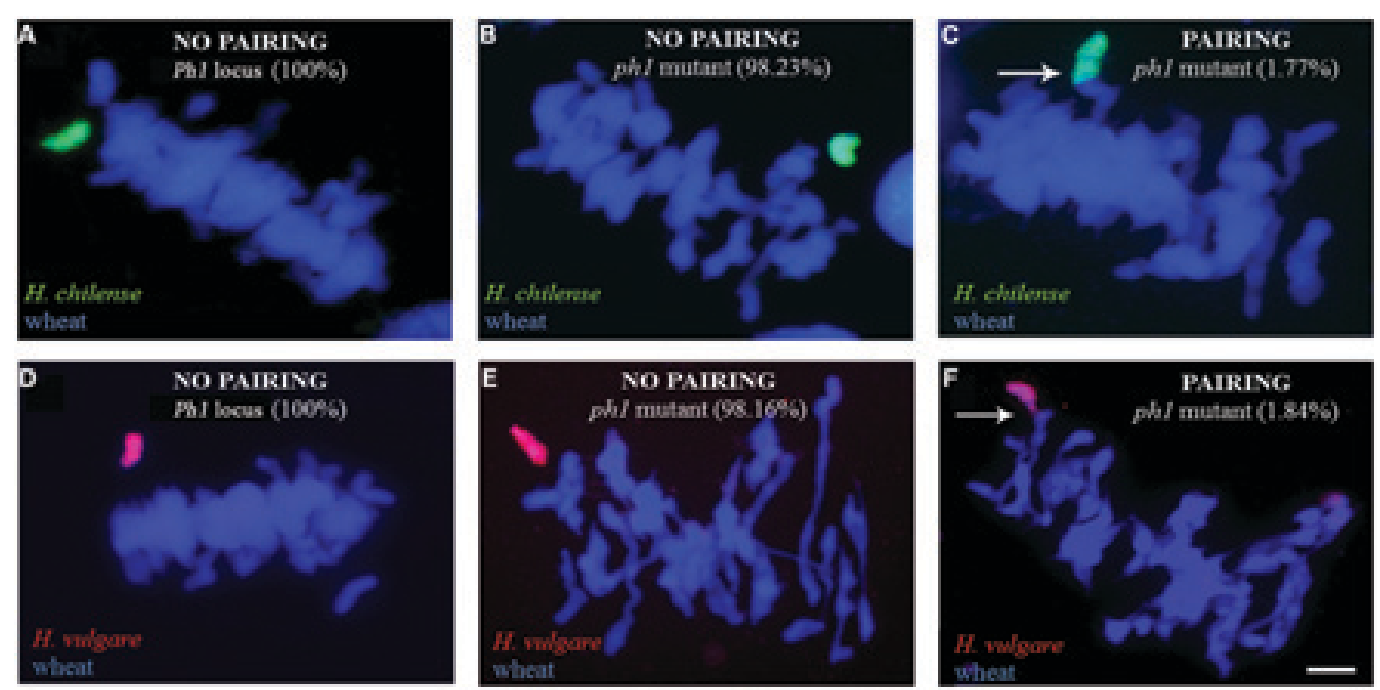

FIGURE 3 | Chromosome pairing at meiotic metaphase I as determined by the allelic status at Ph1. In the presence of Ph1, the Hordeum sp. chromosomes [(A) $7 \mathbf{H}^{\mathrm{ch}}$, shown in green and (D) $4 \mathbf{H}^{\mathbf{v}}$, shown in red] remained unpaired. In a ph1b background, the Hordeum sp. chromosome $\left[(\mathbf{B}) 5 \mathbf{H}^{\text {ch }}\right.$, shown in green and $(\mathbf{E}) \mathbf{7} \mathbf{H}^{\mathbf{v}}$, shown in red] remained as a univalent in most cells. Allosyndesis is induced by the absence of Ph1 between a Hordeum sp. chromosome [(C) $5 \mathbf{H}^{\mathbf{c h}}$, shown in green and (F) $7 \mathbf{H}^{\mathbf{v}}$, shown in red], and a wheat chromosome. Arrows indicate pairing between Hordeum sp.-wheat homoeologs induced by the absence of the Ph1 locus. Bar: $10 \mu \mathrm{m}$.

\section{Materials and Methods}

\section{Plant Materials}

Table 1 lists the various $H$. chilense substitution lines and $H$. chilense and H. vulgare addition lines (Islam et al., 1978, 1981; Miller et al., 1982) used as the female parent in crosses with the ph1b mutant (Sears, 1977). Grains were germinated on wet filter paper in the dark for 5 days at $4^{\circ} \mathrm{C}$, followed by a period of $24 \mathrm{~h}$ at $25^{\circ} \mathrm{C}$. Emerging seedling roots were excised, incubated for $4 \mathrm{~h}$ in $0.05 \% \mathrm{w} / \mathrm{v}$ colchicine at $25^{\circ} \mathrm{C}$, fixed in Carnoy's solution (three parts $100 \%$ ethanol plus one part glacial acetic acid), and finally stored at $4 \mathrm{C}$ for at least 1 month. The plants were subsequently raised in a greenhouse held at $26 \mathrm{C}$ during the day and $22^{\circ} \mathrm{C}$ during the night ( $16 \mathrm{~h}$ photoperiod). Immature spikes were fixed in Carnoy's solution and used to characterize chromosome pairing at meiosis metaphase I.

\section{DNA Marker Characterization}

Genomic DNA was extracted from frozen seedling leaves following Murray and Thompson (1980), as modified by Hernández et al. (2001). The absence of Phl was verified using a PCR assay described by Wang et al. (2002). Each $30 \mu \mathrm{L}$ PCR contained 1x PCR buffer with $\mathrm{MgCl}_{2}$ (Bioline USA, Taunton, MA, USA), $0.25 \mathrm{mM}$ dNTP, $0.17 \mu \mathrm{M}$ primers, $0.02 \mathrm{U} / \mu \mathrm{L}$ Taq DNA polymerase (Bioline USA), and 20 ng template. The reaction was first denatured $\left(94^{\circ} \mathrm{C} / 5 \mathrm{~min}\right)$, and then subjected to 35 cycles of $94^{\circ} \mathrm{C} / 60 \mathrm{~s}, 51^{\circ} \mathrm{C} / 60 \mathrm{~s}$, and $72^{\circ} \mathrm{C} / 60 \mathrm{~s}$, followed by a final extension $\left(72^{\circ} \mathrm{C} / 7 \mathrm{~min}\right)$. The PCR products were electrophoretically separated through a $1 \%$ agarose gel and visualized by EtBr staining. The presence of each Hordeum sp. chromosome was based on PCR assays described by Liu et al. (1996) and Hagras et al. (2005) as detailed in Table 2. The composition of these PCR reactions was as above, while the amplification regime comprised an initial denaturing step $\left(94^{\circ} \mathrm{C} / 5 \mathrm{~min}\right)$, followed by 35 cycles of $94^{\circ} \mathrm{C} / 15 \mathrm{~s}, 50-65^{\circ} \mathrm{C}$ (primer dependent, see Table 2) $/ 30 \mathrm{~s}, 72^{\circ} \mathrm{C} / 60 \mathrm{~s}$, and completed by a final extension $\left(72^{\circ} \mathrm{C} / 6 \mathrm{~min}\right)$. The amplicons were separated as described above.

\section{Cytogenetic Analysis}

Chromosome spreads were prepared from both pollen mother cells (PMCs) at meiotic metaphase I and from root tip cells. 

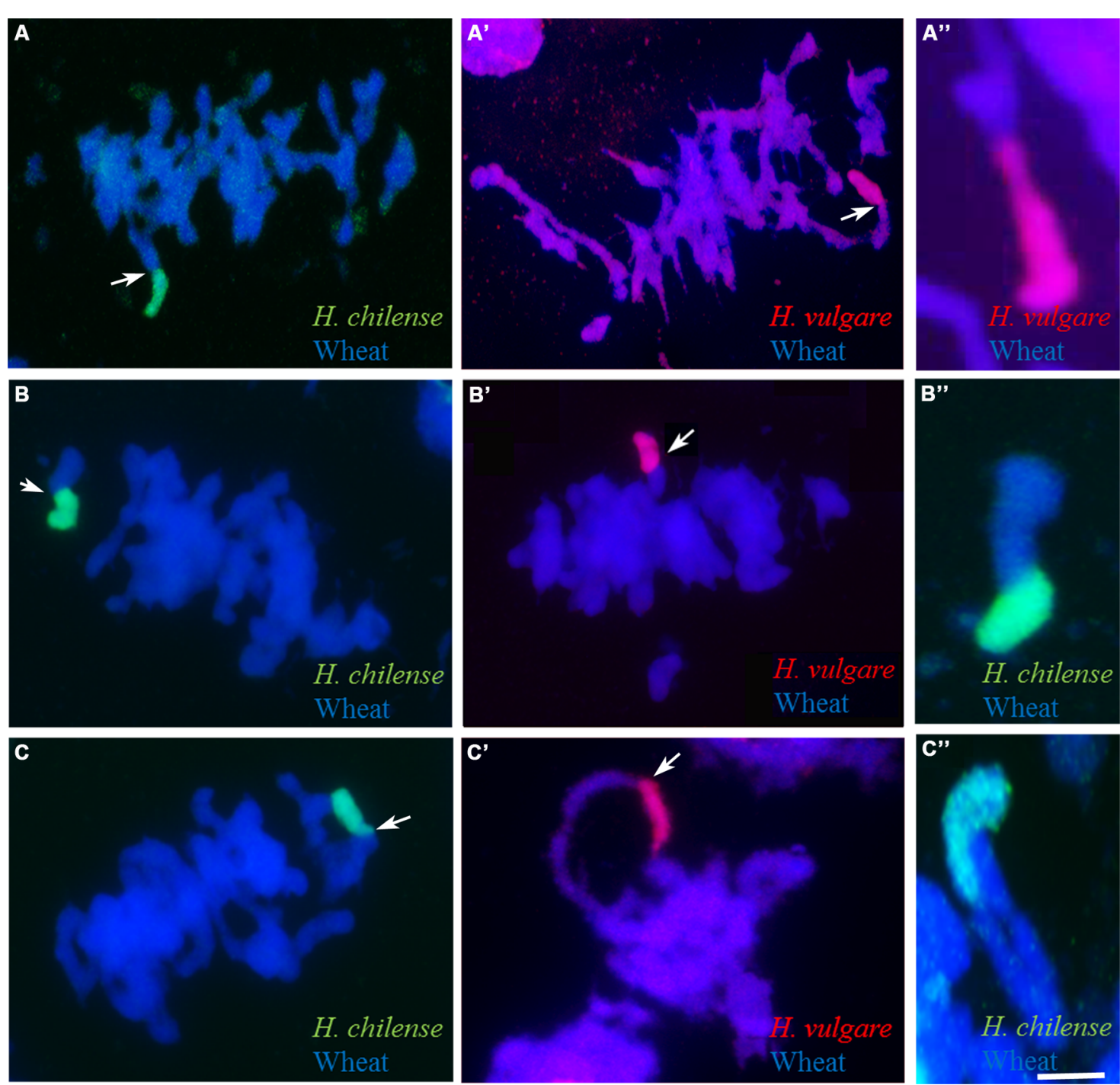

FIGURE 4 | Hordeum sp./wheat chromosome pairing at meiotic metaphase I as detected by GISH. (A-A") Rod bivalents with a sub-terminal chiasma. (B-B") Rod bivalents with a more proximal chiasma. (C-C") A Hordeum sp. chromosome involved in a multivalent. Bar: $10 \mu \mathrm{m}$.

TABLE 4 | (A) The frequency of allosyndesis between individual $H$. chilense or $H$. vulgare chromosomes and those of wheat. (B) The frequency of pairing between specific Hordeum chromosomes and each of their wheat homoeologs.

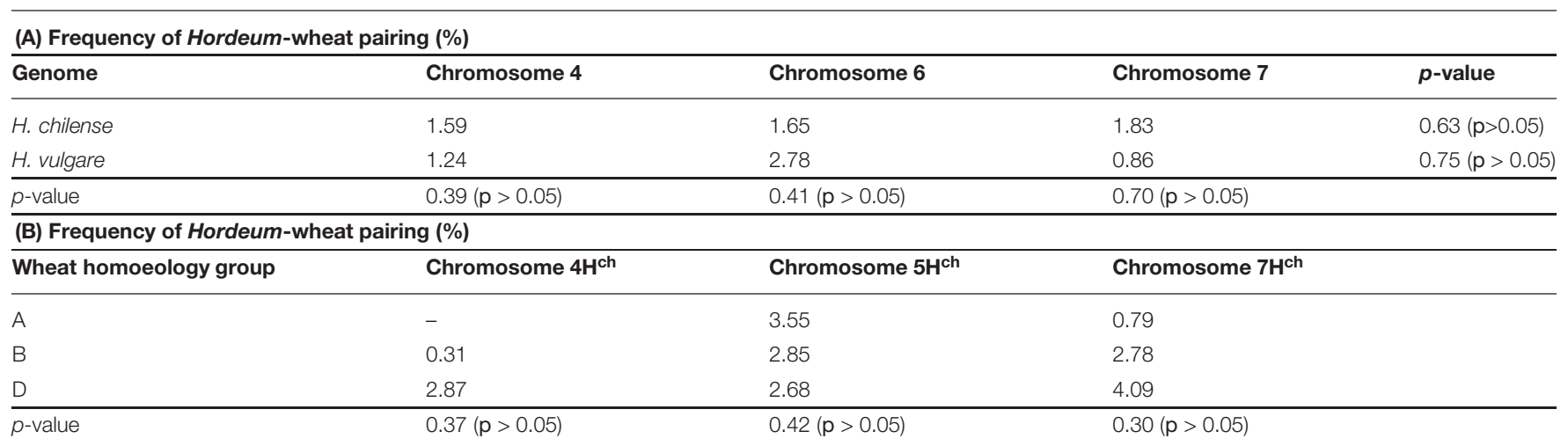


TABLE 5 | $\mathrm{BC}_{1} \mathrm{~F}_{2}$ progeny retaining $\boldsymbol{H}$. chilense or $\boldsymbol{H}$. vulgare chromatin.

\begin{tabular}{|c|c|c|c|c|c|c|c|}
\hline \multirow[t]{3}{*}{ Wheat line } & \multicolumn{7}{|c|}{ No of plants } \\
\hline & \multicolumn{3}{|c|}{ Complete chromosome } & \multirow{2}{*}{$\begin{array}{l}\text { Hordeum-wheat } \\
\text { translocations }\end{array}$} & \multirow{2}{*}{$\begin{array}{l}\text { Telosomic } \\
\text { chromosome }\end{array}$} & \multirow{2}{*}{$\begin{array}{l}\text { Small } \\
\text { introgression }\end{array}$} & \multirow[t]{2}{*}{ Tota } \\
\hline & 2 copies & 1 copy & 0 copies & & & & \\
\hline $\operatorname{CS}(4 B) 4 H^{c h}$ & 2 & 13 & 15 & 0 & 0 & 0 & 30 \\
\hline $\operatorname{CS}(4 D) 4 \mathrm{H}^{\mathrm{ch}}$ & 0 & 15 & 31 & 0 & 0 & $2(4.2 \%)$ & 48 \\
\hline $\operatorname{CS}(5 \mathrm{~A}) 5 \mathrm{H}^{\mathrm{ch}}$ & 0 & 5 & 7 & 0 & 0 & 0 & 12 \\
\hline $\mathrm{CS}(5 \mathrm{~B}) 5 \mathrm{H}^{\mathrm{ch}}$ & 1 & 10 & 18 & $1(3.3 \%)$ & 0 & 0 & 30 \\
\hline $\mathrm{CS}(5 \mathrm{D}) 5 \mathrm{H}^{\mathrm{ch}}$ & 0 & 5 & 15 & 0 & 0 & 0 & 20 \\
\hline $\operatorname{CS}(7 A) 7 H^{c h}$ & 2 & 32 & 37 & $5(6.3 \%)$ & 1 & 0 & 77 \\
\hline $\operatorname{cs}(7 B) 7 H^{c h}$ & 1 & 20 & 37 & $4(6.2 \%)$ & 2 & 0 & 64 \\
\hline $\operatorname{CS}(7 \mathrm{D}) 7 \mathrm{H}^{\mathrm{ch}}$ & 0 & 11 & 26 & $3(7.5 \%)$ & 0 & 0 & 40 \\
\hline $6 \mathrm{H}^{\text {ch }}$ addition & 0 & 8 & 11 & 0 & 1 & 0 & 20 \\
\hline $7 \mathrm{H}^{\mathrm{ch}}$ addition & 2 & 6 & 15 & $2(8 \%)$ & 0 & 0 & 25 \\
\hline $4 \mathrm{H}^{\mathrm{v}}$ addition & 3 & 14 & 28 & 0 & 1 & 0 & 46 \\
\hline $6 \mathrm{H}^{\mathrm{v}}$ addition & 2 & 9 & 11 & 0 & 1 & 0 & 23 \\
\hline $7 \mathrm{H}^{\mathrm{v}}$ addition & 1 & 10 & 25 & 0 & 2 & 0 & 38 \\
\hline Total & 14 & 158 & 276 & 15 & 8 & 2 & 473 \\
\hline
\end{tabular}

Wheat plants carrying stable chromosome introgressions are in bold.

The material was macerated in a drop of $45 \%$ glacial acetic acid, squashed under a cover slip, and dipped in liquid nitrogen in order to remove the cover slip. The preparations were then airdried and either processed directly for in situ hybridization, or stored at $4^{\circ} \mathrm{C}$ until required. The probe used for genomic in situ hybridization was genomic DNA extracted from $H$. chilense (or H. vulgare) seedling leaves. The DNA was labeled with either biotin-11-dUTP (H. vulgare) or digoxigenin-11-dUTP $(H$. chilense; both from Roche Corporate, Basel, Switzerland) by nick-translation. The in situ hybridization protocol followed that described by Prieto et al. (2004). The GAA-satellite sequence (Pedersen et al., 1996) and the pAs1 probe (Rayburn and Gill, 1986) were used to identify chromosomes involved in homoeologous pairing, chromosomal translocations, or chromosomal rearrangements. The GAA-satellite sequence identifies all the $\mathrm{A}$ and $\mathrm{B}$ wheat chromosomes (Pedersen and Langridge, 1997), whereas the pAs1 identifies the D wheat and the $H$. chilense chromosomes (Cabrera et al., 1995). The GAA-satellite sequence and the pAs1 probes were also labeled by nick translation with biotin-11-dUTP and digoxigenin-11dUTP, respectively. Biotin- or digoxigenin-labeled DNA were detected using, respectively, streptavidin-Cy3 (Sigma, St. Louis, MO, USA) and antidigoxigenin-FITC (Roche Applied Science, Indianapolis, IN, USA). After counter-staining with DAPI ( $4^{\prime}$, 6-diamidino-2-phenylindole), the preparations were mounted in Vectashield (Vector Laboratories, Burlingame, CA, USA). Hybridization signals were visualized using a Nikon Eclipse 80i epifluorescence microscopy, and the images captured with a CCD camera (Nikon Instruments Europe BV, Amstelveen, The Netherlands).

\section{Statistical Methods}

Statistical analyses were performed using the STATISTIX v9.0 software (Analytical Software, Tallahassee, FL, USA). Wilcoxon (or $U$ of Mann-Whitney) test was used to determine the statistical significance of differences between means.

\section{Results}

\section{Converting the Substitution and Addition Lines into a ph1b Mutant Background}

The crossing scheme used is illustrated in Figure 1, and the details of the crossing outcomes from the $\mathrm{F} 1$ to the $\mathrm{BC}_{1} \mathrm{~F}_{2}$ generation are given in Table 1 . The $\mathrm{F}_{1}$ hybrid progeny were genotyped by PCR to ensure that they had retained the expected Hordeum sp. chromosome (Table 2; Figure 2A), then crossed again to the ph1b mutant in order to establish individuals in which the Hordeum sp. chromosome was now present in a ph $1 b p h 1 b$ background. Zygosity at the Phl locus was predicted using a PCR assay (Figure 2B). The meiotic behavior of the selected individuals was characterized by GISH analysis of metaphase I in PMCs, and the plants were allowed to self-pollinate.

\section{Allosyndetic Pairing in $\mathrm{BC}_{1} \mathrm{~F}_{1}$ Selections Lacking Ph1}

Meiosis was characterized in $63 \mathrm{BC}_{1} \mathrm{~F}_{1}$ segregants carrying a Hordeum chromosome in the absence of $P h 1$ and compared to those carrying the Hordeum chromosome in its presence (Table 3). No wheat/Hordeum chromosome pairing occurred in plants of genotype Ph1Ph1 (Table 3; Figures 3A,D). In contrast, in the absence of the Ph1 locus, although the Hordeum chromosomes remained unpaired in most metaphase I PMCs (Figures 3B,E), pairing was observed in $1.77 \%$ of the PMCs in $H$. chilense (Table 3; Figure 3C). The equivalent frequency with respect to $H$. vulgare chromosomes was $1.84 \%$ (Table 3; Figure 3F). The frequency of plants displaying wheat/Hordeum chromosome associations was lower in $H$. chilense than in $H$. vulgare (45.23\% and $61.90 \%$, respectively), although variability 

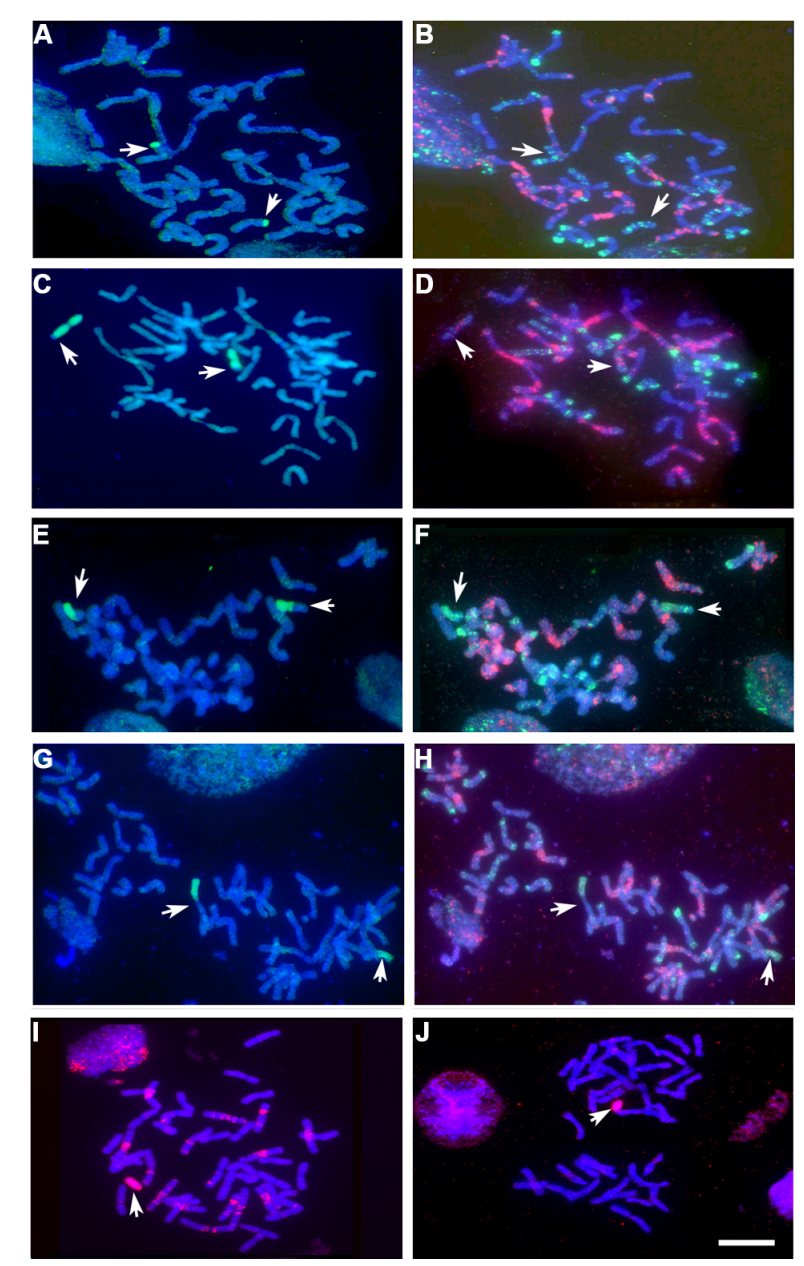

FIGURE 5 | Various forms of introgression (arrowed) detected by GISH (Hordeum chilense and $\boldsymbol{H}$. vulgare genomic introgressions detected in green and red, respectively), and FISH patterns (GAA and pAs1 probes detected in red and green, respectively), in the $\mathrm{BC}_{1} \mathrm{~F}_{2}$ progeny derived from the crosses Hordeum addition/substitution line $x$ ph1b mutant. (A) GISH and (B) FISH pattern of chromosomes of a partial mitotic metaphase carrying two copies of a $4 \mathbf{D}$ chromosome with a distal $4 \mathbf{H}^{\mathrm{ch}} \mathrm{L}$ segment. (C) GISH and (D) FISH pattern of a mitotic metaphase carrying two copies of a $4 \mathbf{H}^{\text {ch }}$ chromosome with a distal $4 \mathbf{D L}$ segment. (E) GISH and (F) FISH pattern of a mitotic metaphase carrying a homocigous $7 \mathbf{H}^{\text {ch }} \mathrm{S}-7 \mathbf{A L}$ Robertsonian translocation. (G) GISH and (H) FISH pattern of a mitotic metaphase carrying a homocigous $7 \mathbf{A S}-7 \mathbf{H}^{\mathbf{c h}} \mathrm{L}$ Robertsonian translocation. (I) GISH of a $4 \mathbf{H}^{\mathbf{v}}$ monotelosomic line. (J) GISH of a $6 \mathbf{H}^{\mathbf{v}}$ monotelosomic line. Bar: $10 \mu \mathrm{m}$.

depending on the specific Hordeum sp. chromosome introgressed was found. Most of the associations between a Hordeum and a wheat chromosome involved the formation of a rod bivalent harboring a single sub-terminal chiasma (Figures $\mathbf{4 A - A}$ "), although in some cases the chiasma occurred more proximally (Figures 4B-B"). In a few PMCs, the Hordeum sp. chromosome formed part of a multivalent (Figures $4 \mathbf{C}-\mathbf{C}^{\prime \prime}$ ) as the result of chiasmata between homoeologous chromosomes, or reflecting the re-arrangement of the wheat genome induced by successive meiosis during the generations of selfing used to maintain the ph1b mutant stock. Wilcoxon test showed that the frequency of allosyndesis was not Hordeum sp. chromosome specific, since there was no significant difference in pairing frequency between either chromosomes $4 \mathbf{H}^{\mathrm{ch}}, 6 \mathbf{H}^{\mathrm{ch}}$, and $7 \mathbf{H}^{\mathrm{ch}}$ or between chromosomes $4 \mathbf{H}^{\mathbf{v}}, 6 \mathbf{H}^{\mathbf{v}}$, and $7 \mathbf{H}^{\mathbf{v}}$ (Table $4 \mathbf{A}$ ). In addition, using the same statistical test, no significance differences where found when compared the effect of the genome ( $H$. chilense or $H$. vulgare) for the same homoeologous group $(p=0.39,0.41$, and 0.70 for chromosomes 4, 6, and 7, respectively; Table 4A). A statistical comparison of chromosome pairing frequency involving a $H$. chilense chromosome and each of its wheat homoeologs was also carried out and showed no evidence for any preferential pairing (Table 4B).

\section{Genetic Evidence for Hordeum sp. Introgression Induced by the Absence of Ph1}

A total of $473 \mathrm{BC}_{1} \mathrm{~F}_{2}$ progeny were analyzed by GISH analysis to detect and characterize Hordeum sp. chromosome rearrangements in the background of the ph $1 b$ mutant. About $60 \%$ of the progeny lacked any Hordeum sp. chromatin. Overall, with respect to the Hordeum sp. chromosome, about 3\% of the progeny were disomic and about 33\% were monosomic. The highest transmission rate of a Hordeum chromosome was observed among the progeny derived from the (4B) $4 \mathbf{H}^{\text {ch }}$ substitution line. Two recombinants were identified, both involving chromosomes $4 \mathbf{H}^{\text {ch }}$ and $4 \mathbf{D}$ (Table 5; Figures 5A-D). A total of 15 individuals harbored a Robertsonian translocation involving a $H$. chilense (chromosome $5 \mathbf{H}^{\text {ch }}$ : one plant, chromosome $7 \mathbf{H}^{\text {ch }}$ : 14 plants) and the homoeologous wheat chromosomes $5 \mathbf{B}$ and 7A, respectively (Table 5; Figures 5E-H). Telosomic chromosomes resulting from misdivision were observed in eight plants, affecting chromosomes $6 \mathbf{H}^{\mathrm{ch}}, 7 \mathbf{H}^{\mathrm{ch}}, 4 \mathbf{H}^{\mathbf{v}}, 6 \mathbf{H}^{\mathbf{v}}$, and $7 \mathbf{H}^{\mathbf{v}}$ (Table 5; Figures 5I,J).

\section{Discussion}

Interspecific hybridization retains its potential to widen the gene pool available to the wheat breeder. Combining in situ hybridization with DNA-based genotyping has eased the process considerably since the initial efforts which followed the recognition that recombination could be induced by the deletion of $P h 1$ (Koebner and Shepherd, 1986; Qi et al., 2007). An in situ hybridizationbased screening strategy has previously been applied to characterize introgressions from both $H$. chilense and $H$. vulgare, resulting in the recognition of a number of wheat/Hordeum sp. translocations (Prieto et al., 2001). Here, the intention was to exploit the abolition of strict homologous pairing induced by the absence of $P h 1$ to generate material where recombination had shortened the length of the introgressed segment. Chromosome $4 \mathbf{H}^{\text {ch }}$ is of particular interest as it harbors a gene (or possibly genes) encoding resistance against the fungal pathogen Septoria tritici (Rubiales et al., 2000). Two recombinants involving chromosome $4 \mathbf{H}^{\text {ch }}$ were obtained in this work as the results of the same recombination event between $4 \mathrm{DL}$ and $4 \mathbf{H}^{\mathrm{ch}} \mathrm{L}$ chromosome arms, and can help to locate those resistance genes on chromosome $4 \mathbf{H}^{\text {ch }} \mathrm{L}$. Similarly, chromosome $7 \mathbf{H}^{\text {ch }}$ has been targeted for its positive 
effect on grain carotenoid content (Alvarez et al., 1999), and chromosome $5 \mathbf{H}^{\text {ch }}$ for its contribution to enhancing salinity tolerance (Forster et al., 1990). Although inter-chromosome translocations are known to occur spontaneously (Mettin et al., 1973; Zeller, 1973; Prieto et al., 2001), and can be induced by ionizing radiation and the action of certain gametocidal genes (Sears, 1956, 1993; Endo, 1988, 1990; Endo and Gill, 1996), the particular advantage of exploiting the ph1b mutant to promote allosyndesis is that the translocations are non-random: rather, they tend to involve the exchange of genetically related material. Its disadvantage is that the frequency of allosyndesis (and hence of recombination) is rather low, especially between chromosomes of more distantly related genomes such as Triticum and Hordeum. The level of $p h 1 b$-induced pairing between wheat and cereal rye (Secale cereale) chromosomes has been estimated to be around $4 \%$ (Miller et al., 1994), which is about double the level noted here between the chromosomes of wheat and either of the two Hordeum sp. Moreover, the frequency of recombination was correlated with the frequency of wheat-rye pairing in metaphase $\mathrm{I}$ in ABDR hybrids in the absence of the Phl locus (Naranjo and Fernández-Rueda, 1996). However, an extensive ph1b-based attempt to reduce the length of the rye chromosome segment present in the widely used wheat/rye Robertsonian translocation 1BL.1RS resulted in an estimated recombination frequency of only around $0.7 \%$ (Koebner and Shepherd, 1986; Lukaszewski, 2000). The levels achievable in more closely related species, notably in the genus Aegilops (Riley et al., 1968a; Gill and Raupp, 1987; Koebner and Shepherd, 1987; Farooq et al., 1990; Ceoloni et al., 1992), are much higher than this.

Our results showed that homoeologous recombination between Hordeum sp. and wheat chromosomes did only depend

\section{References}

Alvarez, J. B., Martín, L. M., and Martín, A. (1999). Genetic variation for carotenoid pigment content in the amphiploid Hordeum chilense $\mathrm{x}$ Triticum turgidum conv. durum. Plant Breed. 118, 187-189. doi: 10.1046/j.14390523.1999.118002187.x

Benavente, E., Fernández-Calvín, B., and Orellana, J. (1996). Relationship between the levels of wheat-rye metaphase I chromosomal pairing and recombination revealed by GISH. Chromosome 105, 92-96. doi: 10.1007/BF02509518

Cabrera, A., Friebe, B., Jiang, J., and Gill, B. S. (1995). Characterization of Hordeum chilense chromosomes by C-banding and in situ hybridization using highly repeated DNA probes. Genome 38, 435-442. doi: 10.1139/g95-057

Calderón, M. C., Rey, M. D., Cabrera, A., and Prieto, P. (2014). The subtelomeric region is important for chromosome recognition and pairing during meiosis. Sci. Rep. 4, 6488. doi: 10.1038/srep06488

Ceoloni, C., del Signore, G., Ercoli, L., and Donini, P. (1992). Locating the alien chromatin segment in common wheat-Aegilops longissima mildew resistant transfers. Hereditas 116, 239-245. doi: 10.1111/j.1601-5223.1992.tb00148.x

Endo, T. R. (1988). Induction of chromosomal structural changes by a chromosome of Aegilops cylindrica L. in common wheat. J. Hered. 79, 366-370.

Endo, T. R. (1990). Gametocidal chromosomes and their induction of chromosome mutations in wheat. Jpn. J. Genet. 65 , 135-152. doi: 10.1266/jjg.65.135

Endo, T. R., and Gill, B. S. (1996). The deletion stocks of common wheat. J. Hered. 87, 295-307.

Farooq, S., Shah, T. M., and Iqbal, N. (1990). Variation in crossability among intergeneric hybrids of wheat and salt tolerant accessions of three Aegilops species. Cereal Res. Commun. 18, 335-338.

Forster, B. P., Phillips, M. S., Miller, T. E., Baird, E., and Powell, W. (1990). Chromosome location of genes controlling tolerance to salt $(\mathrm{NaCl})$ and on the absence of the Ph1 locus as no differences in the frequency of pairing were found when chromosome association in different homoeologous groups was studied. Most of chromosome associations between Hordeum sp. and wheat chromosomes were end-to-end extremely distal associations as described previously (Werner et al., 1992; Benavente et al., 1996; Calderón et al., 2014).

In summary, the use of the phlb mutant does induce a low, but significant level of chromosome pairing and recombination between wheat and Hordeum sp. chromosomes. The translocation and introgression chromosomes detected in the present work will serve as potential donor material for the breeding of cultivars having a higher grain carotenoid content, stronger resistance against $S$. tritici and improved salinity tolerance.

\section{Author Contributions}

M-DR, MC, and PP carried out the experiments and analyzed the data. M-DR and PP planned the study and wrote the manuscript. All authors read and approved the final manuscript.

\section{Acknowledgments}

The authors are grateful to Steve Reader (John Innes Centre, Norwich, UK) for the gift of the necessary cytogenetic stocks. This research was supported by grant ERC-StG-243118 awarded by the European Union under FP7 and The European Regional Development Fund (FEDER).

vigour in Hordeum vulgare and H. chilense. Heredity 65, 99-107. doi: 10.1038/hdy.1990.75

Gill, B. S., and Raupp, W. J. (1987). Direct genetic transfers from Aegilops squarrosa L. to hexaploid wheat. Crop Sci. 27, 445-450.

Hagras, A. A. A., Masahiro, K., Tanaka, K., Sato, K., and Tsujimoto, H. (2005). Genomic differentiation of Hordeum chilense from $H$. vulgare as revealed by repetitive and EST sequences. Genes Genet. Syst. 80, 147-159. doi: $10.1266 /$ ggs.80.147

Hernández, P., Dorado, G., Prieto, P., Jiménez, M. J., Ramírez, M. C., Laurie, D. A., et al. (2001). A core genetic map of Hordeum chilense and comparisons with maps of barley (Hordeum vulgare) and wheat (Triticum aestivum). Theor. Appl. Genet. 102, 1259-1264. doi: 10.1007/s001220 000514

Islam, A. K. M. R., Shepherd, K. W., and Sparrow, D. H. B. (1978). Production and characterization of wheat-barley addition lines. Paper Presented at the Proceedings of the 5th International Wheat genetics Symposium, Science Publishers Inc, India, 356-371.

Islam, A. K. M. R., Shepherd, K. W., and Sparrow, H. B. (1981). Isolation and characterization of euplasmic wheat-barley chromosome addition lines. Heredity 46, 161-174. doi: 10.1038/hdy.1981.24

Khan, I. A. (1999). Detection of wheat-alien recombinant chromosomes using co-dominant DNA markers. Ann. Appl. Biol. 135, 579-583. doi: 10.1111/j.17447348.1999.tb00889.x

Koebner, R. M. D., and Shepherd, K. W. (1986). Controlled introgression to wheat of genes from rye chromosome arm 1RS by induction of allosyndesis. Theor. Appl. Genet. 73, 197-208. doi: 10.1007/BF00289275

Koebner, R. M. D., and Shepherd, K. W. (1987). Allosyndetic recombination between a chromosome of Aegilops umbellulata and wheat chromosomes. Heredity 59, 33-45. doi: 10.1038/hdy.1987.94 
Liu, W., Jin, Y., Rouse, M., Friebe, B., Gill, B., and Pumphrey, M. O. (2011). Development and characterization of wheat-Ae. searsii robertsonian translocations and a recombinant chromosome conferring resistance to stem rust. Theor. Appl. Genet. 122, 1537-1545. doi: 10.1007/s00122-011-1553-4

Liu, Z. W., Biyashev, R. M., and Saghai Maroof, M. A. (1996). Development of simple sequence repeat DNA markers and their integration into a barley linkage map. Theor. Appl. Genet. 93, 869-876. doi: 10.1007/BF00224088

Lukaszewski, A. J. (2000). Manipulation of the 1RS.1BL translocation in wheat by induced homoeologous recombination. Crop Sci. 40, 216-225. doi: 10.2135/cropsci2000.401216x

Martín, A., Cabrera, A., Hernández, P., Ramirez, M. C., Rubiales, D., and Ballesteros, J. (2000). Prospect for the use of Hordeum chilense in durum wheat breeding. Paper Presented at the Durum Wheat Improvement in the Mediterranean Region: New Challenges Options Méditerranées, Zaragoza.

Martín, A., Martín, L. M., Cabrera, A., Ramirez, M. C., Jimenez, M. J., and Rubiales, D. et al. (1998). The potential of Hordeum chilense in breeding Triticeae species. Paper Presented at the Triticeae III (Enfield, NH: Science Publishers), 377-386.

Martín, A., and Sanchez-Mongelaguna, E. (1982). Cytology and morphology of the amphiploid Hordeum chilense x Triticum turgidum conv. durum. Euphytica 31, 261-267. doi: 10.1007/BF00028329

Mettin, D., Bltithner, W. D., and Schlegel, R. (1973). Additional evidence on spontaneous 1B/1R wheat-rye substitutions and translocations. Paper Presented at the Proc 4th International Wheat Genetics Symposium, University of Missouri, Columbia, MO, 79-184.

Miller, T. E., Reader, S. M., and Chapman, V. (1982). The addition of Hordeum chilense chromosomes to wheat. Paper Presented at the Proceedings of the International Symposium Eucarpia on Induced Variability in Plant Breeding. Pudoc, Wageningen, 79-81.

Miller, T. E., Reader, S. M., Purdie, K. A., and King, I. P. (1994). Determination of the frequency of wheat-rye chromosome pairing in wheat $\mathrm{x}$ rye hybrids with and without chromosome 5B. Theor. Appl. Genet. 89, 255-258.

Moore, G. (2014). "The control of recombination in wheat by Ph1 and its use in breeding," in Methods in Molecular Biology, ed. N. J. Clifton (New York, NY: Humana Press), 143-153.

Murray, M. G., and Thompson, W. F. (1980). Rapid isolation of high molecular weight plant DNA. Nucleic Acids Res. 8, 4321-4326. doi: 10.1093/nar/8.19.4321

Naranjo, T., and Fernández-Rueda, P. (1996). Pairing and recombination between individual chromosomes of wheat and rye in hybrids carrying the phlb mutation. Theor. Appl. Genet. 93, 242-248. doi: 10.1007/BF00225752

Pedersen, C., and Langridge, P. (1997). Identification of the entire chromosome complement of bread wheat by two-color FISH. Genome 40, 589-593. doi: 10.1139/g97-077

Pedersen, C., Rasmussen, S. K., and Linde-Laursen, I. (1996). Genome and chromosome identification in cultivated barley and related species of the Triticeae (Poaceae) by in situ hybridization with the GAA-satellite sequence. Genome 39, 93-104. doi: 10.1139/g96-013

Prieto, P., Martín, A., and Cabrera, A. (2004). Chromosomal distribution of telomeric and telomeric-associated sequences in Hordeum chilense by in situ hybridization. Hereditas 141, 122-127. doi: 10.1111/j.1601-5223.2004.01825.x

Prieto, P., Ramirez, M. C., Ballesteros, J., and Cabrera, A. (2001). Identification of intergenomic translocations involving Wheat, Hordeum vulgare and Hordeum chilense chromosomes by FISH. Hereditas 135, 171-174. doi: 10.1111/j.16015223.2001.t01-1-00171.x

Qi, L. L., Friebe, B., Zhang, P., and Gill, B. S. (2007). Homoeologous recombination, chromosome engineering and crop improvement. Chromosome Res. 15, 3-19. doi: 10.1007/s10577-006-1108-8

Qi, L. L., Pumphrey, M. O., Friebe, B., Chen, P. D., and Gill, B. S. (2008). Molecular cytogenetic characterization of alien introgressions with gene Fhb3 for resistance to Fusarium head blight disease of wheat. Theor. Appl. Genet. 117, 1155-1166. doi: 10.1007/s00122-008-0853-9

Rayburn, A. L., and Gill, B. S. (1986). Isolation of a D-genome specific repeated DNA sequence from Aegilops squarrosa. Plant Mol. Biol. Report. 4, 102-109. doi: 10.1007/BF02732107
Riehl, S., Zeidi, M., and Conard, N. J. (2013). Emergence of agriculture in the foothills of the Zagros Mountains of Iran. Science 341, 65-67. doi: 10.1126/science. 1236743

Riley, R., and Chapman, V. (1958). Genetic control of the cytologically diploid behavior of hexaploid wheat. Nature 182, 713-715. doi: 10.1038/18 $2713 \mathrm{a} 0$

Riley, R., Chapman, V., and Johnson, R. (1968a). The incorporation of alien disease resistance in wheat by genetic interference with the regulation of meiotic chromosome synapsis. Genet. Res. 12, 199-219. doi: 10.1017/S00166723000 11800

Riley, R., Chapman, V., and Johnson, R. (1968b). Introduction of yellow rust resistance of Aegilops comosa into wheat by genetically induced homoeologous recombination. Nature 217, 383-384. doi: 10.1038/217 $383 \mathrm{a} 0$

Rubiales, D., Reader, S. M., and Martín, A. (2000). Chromosomal location of resistance to Septoria tritici in Hordeum chilense determined by the study of chromosomal addition and substitution lines in 'Chinese Spring' wheat. Euphytica 115, 221-224. doi: 10.1023/A:1004097830103

Salamini, F., Özkan, H., Brandolini, A., Schäfer-Pregl, R., and Martín, W. (2002). Genetics and geography of wild cereal domestication in the near east. Nat. Rev. Genet. 3, 429-441. doi: 10.1038/nrg817

Sears, E. R. (1956). Transfer of leaf-rust resistance from Aegilops umbellulata to wheat. Brookhaven Symp. Biol. 9, 1-21.

Sears, E. R. (1976). Genetic control of chromosome pairing in wheat. Ann. Rev. Genet. 10, 31-51. doi: 10.1146/annurev.ge.10.120176.000335

Sears, E. R. (1977). Induced mutant with homoeologous pairing in common wheat. Can. J. Genet. Cytol. 19, 585-593.

Sears, E. R. (1981). "Transfer of alien genetic material to wheat," in The Wheat Science-today and Tomorrow, eds L. D. Evans and W. J. Peacock (Cambridge: Cambridge University Press, UK), 75-89.

Sears, E. R. (1982). A wheat mutation conditioning an intermediate level of homoeologous chromosome pairing. Can. J. Genet. Cytol. 24, 715-719. doi: $10.1139 / g 82-076$

Sears, E. R. (1993). Use of radiation to transfer alien chromosome segments to wheat. Crop Sci. 33, 897-901. doi: 10.2135/cropsci1993.0011183X003300050004x

Sears, E. R., and Okamoto, M. (1958). Intergenomic chromosome relationship in hexaploid wheat. Paper Presented at the Proceedingsof the 10th International. Congress of Genetics, Montreal, 258-259.

Wang, X., Lai, J., Liu, G., and Chen, F. (2002). Development of a Scar marker for the Ph1 locus in common wheat and its application. Crop Sci. 42, 1365-1368. doi: 10.2135/cropsci2002.1365

Werner, J. E., Endo, T. R., and Gill, B. S. (1992). Toward a cytogenetically based physical map of the wheat genome. Proc. Natl. Acad. Sci. U.S.A. 89, 11307-11311. doi: 10.1073/pnas.89.23.11307

Zeller, F. J. (1973). 1B/1R substitutions and translocations. Paper Presented at the Proceedings of the 4th International Wheat Genetetics Symposium, University of Missouri, Columbia, MO, 209-221.

Zhao, R., Wang, H., Xiao, J., Bie, T., Cheng, S., Jia, Q., et al. (2013). Induction of 4 VS chromosome recombinants using the CS ph1b mutant and mapping of the wheat yellow mosaic virus resistance gene from Haynaldia villosa. Theor. Appl. Genet. 126, 2921-2930. doi: 10.1007/s00122-013-2181-y

Conflict of Interest Statement: The authors declare that the research was conducted in the absence of any commercial or financial relationships that could be construed as a potential conflict of interest.

Copyright (C) 2015 Rey, Calderón and Prieto. This is an open-access article distributed under the terms of the Creative Commons Attribution License (CC BY). The use, distribution or reproduction in other forums is permitted, provided the original author(s) or licensor are credited and that the original publication in this journal is cited, in accordance with accepted academic practice. No use, distribution or reproduction is permitted which does not comply with these terms. 